consists of J. H. Schuurmans Stekhoven, J. W. Seinhorst, M. Oostenbrink, and P. A. van der Laan, of the Netherlands; they are assisted by advisory editors from fourteen countries, including the United States and the U.S.S.R., with F. G. W. Jones and B. G. Peters from Great Britain. The first issue (1, No. $1 ;$ 1956. Pp. $80+10$ plates. Leyden: E. J. Brill ; 28 florins per volume of four parts) contains about half the communications to the above symposium, and the second is to contain the remainder. The editors state that, in consequence, these two issues will not be representative of future issues, for the communications were all relatively short and most of them in the field of agricultural nematology. Although future issues are to be concerned primarily with this aspect, it is hoped that the journal will cover the field of nematology in general, "except for papers on medical and veterinary subjects", and will also include studies in "taxonomy, physiology, morphology, genetics, and other more fundamental research". The journal also incorporates the Nematological News of Dr. A. H. Meyl (Germany); in the first issue, two pages of small print are devoted to this very useful feature.

\section{Geographical Trends in the Soviet Union}

IN the September issue of the Russian journal, Nauka $i$ Zhizn (Science and Life), K. V. Zvorykkin and G. M. Ignat'ev emphasize the importance of a closer connexion between geographical exploration and agriculture, as exemplified by some recent surveys by the Geography Department of the University of Moscow. Both geology and geography, they write, must to-day subserve strictly practical and utilitarian ends, with perhaps less of the glamour and adventure that enlivened the exploits of old. The former must be used for seeking far and wide for new oilfields or promising formations, and the latter for exploring throughout the length and breadth of the vast Soviet territories for more farmland to meet the rapidly increasing needs of a growing population and rising standard of living. However, the surveys they describe did not go very far afield : they went no farther, indeed, than Ryazan, which is practically in the Central Russian or Moscow region, and is not so very distant south-east from the University itself. The expeditions were mainly intended as practice and experience in agricultural survey work for the students and others, more particularly on existing or potential collective farms and the domains of the tractor service stations usually associated with several of such farms. State farms, too, were included. The first expedition was mainly confined to Zaraisk, a district of the Ryazan Government, and the second was called the Ryazan Expedition, though it too was limited to a relatively few collective farms in the Sapozhkovsk locality. Both aimed at providing as much information as possible from the point of view of the potential farmlands, including detailed maps, soil science, climatology, contours and water supply, and also some indication of the measures needed to make the land suitable for cultivation and optimum use. Though students from many other departments in the University took part-physical and economic geographers, geophysicists and cartographers, soil geographers, biogeographers, etc.-it would seem that the services of economic botanists, entomologists, and even zoologists and scientific stock-broeders would be needed to make a complete and really informative study, and these are not mentioned (unless included under biogeographers). Zvorykin and Ignat'ev are firmly convinced that. in conformity with the far-reaching and ambitious economic planning for Soviet industry and agriculture, as set forth in some detail at each succeeding plenary session of the Central Committee, geographers must considerably broaden their ideas; they must even extend the range and variety of their work beyond that of agricultural requirements to the industrial field generally, for example, in surveying suitable river sites for hydroelectric stations.

\section{Forest Products Research during 1954}

THE annual report for 1954 of the Forest Products Research Laboratory, Princes Risborough (pp. 60+ 8 plates. London: H.M.S.O., $1955 ; 3 s .6 d$. net), shows that the scope and nature of the work undertaken have remained the same; the contact between the Laboratory and the trades and others interested in the utilization of timber and its products have been close, and the number of inquiries reaching the Laboratory is still on the increase. One significant change in the work has been a decrease in the emphasis on the testing and assessment of new Colonial timbers which has formed such an important and valuable part of the work of the Laboratory during past years, more time having been devoted to the examination of various species of home-grown timber in co-operation with the Forestry Commission. Now that the new plantations are reaching a size when thinnings can be made in them, the strength or degree of these thinnings in various species of crops is undergoing sylvicultural experiment. As the work proceeds, with the increase in age and size of the wood, the Laboratory will be able to give valuable assistance in testing the timber quality of the various species being used, the soils on which they are grown and various other locality factors, including the management applied. Tests of timber seasoning and important plywood experiments are under investigation. The Entomology Section reports the discovery of the house longicorn beetle in Surrey a few years ago. It is a menace to softwood structural timbers and is well known on the Continent of Europe. So far, in spite of careful investigation, it has only been found in a comparatively restricted area in Surrey. It is said to attack the hardwood oak in Great Britain. The death-watch beetle has been under study for some timo in the Section.

\section{Australian Earthworms}

THE longest earthworm in the world, Megascolides australis, is found in Gippsland, Australia, and grows up to eleven feet in length. Its habit of 'squirting' has been described by Elizabeth C. Pope (Austral. Mus. Mag., 11, No. 12; December 1955). When disturbed, the worm squirts out a series of pairs of jets of fluid from a line of pores opening down each side of the body. The effect can be most spectacular, for these jets rise as high as eighteen inches or two feot into the air. Although there are reports that the fluid has a corrosive action, it is only slightly alkaline and contains some dissolved salts, body wastes like urea and some proteinous materials and cells. The fluid comes from the worm's body cavity and is squirted out by violent contractions of the body-wall which force the fluid out under great pressure through the pores. There is no record of the fluid having anything but a mildly irritating effect on the skin of human beings. The fluid is used for lining or lubricating the burrows of the worms. The article also refers to other 'squirter' earthworms. 